\title{
СТИМУЛИРОВАНИЕ ПОВЫШЕНИЯ ЭФФЕКТИВНОСТИ ПЕРЕРАБАТЫВАЮЩИХ ПРЕДПРИЯТИЙ АПК
}

\author{
(c) 2019 Луценко Татьяна Сергеевна \\ преподаватель Факультета дополнительного образования \\ Курский институт менеджмента, экономики и бизнеса, Россия, Курск \\ E-mail:1tsdom@mail.ru
}

Статья посвящена рассмотрению налоговых стимулов повышения эффективности перерабатывающих предприятий АПК. Установлена возможность повышения эффективности на основе более полного использования имеющихся резервов действующего Налогового кодекса РФ. Предложены и обоснованы пониженные ставки налога на прибыль для перерабатывающих предприятий АПК.

Ключевые слова: эффективность, рентабельность, стимулирование эффективности, перерабатывающие предприятия АПК, ставка налога на прибыль.

В связи со значительными изменениями экономических условий производства в России, в последнее время наблюдается повышенное внимание ученых к вопросам связанныс с экономической эффективностью предприятий. Так, Н.П. Грибалев и И.П. Игнатьева пишут: «Ускорение изменений в окружающей среде, появление новых запросов и изменение позиции потребителя, появление новых возможностей для бизнеса, развитие информационных сетей, широкая доступность современных технологий, изменение роли человеческих ресурсов, и другие причины привели к возрастанию значения выработки эффективности развития организации» [1].

Другие экономисты обосновывают необходимость роста эффективности предприятий. Так, Э.С. Набиуллина отмечает: «Время, когда конкурентоспособность поддерживалась дешевизной сырья, рабочей силы и заниженным курсом рубля уходит в прошлое. Постоянное удорожание энергоносителей ведет к увеличению издержек предприятий. Эта тенденция вряд ли изменится в ближайшие годы. И единственный адекватный ответ, который наша экономика должна дать на этот вызов,- значительное повышение эффек- тивности...» [5].

В действующих экономических условиях, на перерабатывающих предприятиях АПК, возникает ряд проблем, требующих своевременного решения. Так, несмоотря на сохранение положительной динамики 2018 году в пищевой и перерабатывающей промышленности РФ (индекс производства пищевых продуктов составил 104,9\%, в январе-ноябре 2017 года - 104,7\%) [12] и росте в целом по агропромышленному комплексу на 2,3\% [13] в отдельных регионах наблюдается сокращение числа предприятий АПК вследствие их низкой эффективности. Например, в Курской области число сельскохозяйственных предприятий с 2013 года по 2017 год постоянно сокращалось.

С целесообразностью развития производства на основе роста его эффективности согласны практически все экономисты. Однако этот процесс не может развиваться самостоятельно, он требует к себе постоянного внимания и существенных дополнительных усилий. Более того развитие производства на основе роста эффективности сопряжено с расходованием значительных ресурсов.

Для увеличения эффективности действу-

Таблица 1. Количество предприятий по годам [10].

\begin{tabular}{|c|c|c|}
\hline Год & $\begin{array}{c}\text { Число предприятий по виду экономической деятельности } \\
\text { сельское хозяйство (охота и лесное хозяйство) }\end{array}$ & Регион \\
\hline 2013 & 1190 & Курская область \\
\hline 2014 & 1165 & Курская область \\
\hline 2015 & 1051 & Курская область \\
\hline 2016 & 977 & Курская область \\
\hline 2017 & 946 & Курская область \\
\hline
\end{tabular}


ющих перерабатывающих предприятий АПК необходимо выполнить комплекс различных мероприятий, приложить дополнительные организационные усилия, а так же покрыть значительные финансовые, материальные и иные затраты. При этом объективно возрастают риски возникновения невозвратных потерь и убытков. Поэтому, не во всех случаях усилия предприятий приводят к желаемому росту их эффективности.

Следует так же отметить, что рост прибыли, достигнутый в результате повышения эффективности, влечет увеличение налоговых отчислений. Фактически действующая в РФ система налогообложения не содержит элементов стимулирующих рост эффективности предприятий.

Если рассматривать налогообложение дохода предприятий в развитых странах, то можно заметить следующее. «К общим чертам налогообложения АПК в зарубежных странах можно отнести их единую классификацию (прямые, косвенные и социальные налоги), а также льготный режим их уплаты. Объектом прямых налогов в данной отрасли являются доходы, которые облагаются подоходным налогом или налогом на прибыль (корпоративным). Кроме того, объектом обложения также становится имущество (земельный и имущественный налог на недвижимость). Налог на прибыль или корпоративный налог уплачивают в основном организации (кооперативы, предприятия), а подоходный налог - фермеры и другие работники АПК» [11].

«Ставки и льготы по прямым налогам от доходов значительно дифференцируются по отдельным странам и в большинстве случаев зависят от размеров и масштабов деятельности облагаемого объекта и специфики самого плательщика. Так, в Великобритании ставка по корпоративному налогу была определена в размере от 5 до 40\%, в Италии - от 12 до 62\%, в Нидерландах - от 16 до 72\%, в США - от 15 до 28\%, а для крупных компаний $-35 \%$ » [2].

Отсутствие дифференциации ставка налога на прибыль в нашей стране не стимулирует рост эффективности предприятий, а напротив содержит элементы сдерживающие его. В то же время, заинтересованностью роста эффективности предприятий должна быть проникнута вся система взаимоотношений предприятий и государства, так как это является важнейшим элементом обеспечивающим процветание страны. Поэтому, можно утверждать, что применяемая система налогообложения должна быть нацеле- на на формирование заинтересованности предприятий в росте эффективности. Следовательно, налогообложение должно содержать в себе систему стимулирования повышения эффективности предприятий.

В связи с этим существует потенциальная возможность дополнить существующую систему налогообложения элементами, которые экономически заинтересуют предприятия повышать эффективность деятельности.

Необходимо отметить, что согласно действующего Налогового кодекса РФ (п. 1 ст. 284 НК РФ) [6], ставка налога на прибыль составляет 20\%. С 01.01.2017 плательщики налога на прибыль обязаны вносить:

- сумму по ставке 3\% - в федеральную составляющую госбюджета;

- сумму по поставке $17 \%$ - в региональную составляющую госбюджета.

При этом в период 2017-2020 годы региональные власти могут снижать ставку налога для отдельных категорий налогоплательщиков до 12,5\% (вместо действующей 17\%), т.е. на 4,5\%. Снижение ставки должно оформляться принятием закона на уровне субъекта РФ (абз. 4 п. 1 ст. 284 НК РФ) [6].

В сложившихся экономических условиях, для поощрения роста эффективности перерабатывающих предприятий АПК, целесообразно стимулировать повышение их эффективности через налог на прибыль. Для этого на предприятиях добившихся увеличения рентабельности (отношение прибыли до налогообложения к выручке) относительно предыдущего налогового периода, следует сделать возможным, исчислять налог на прибыль по пониженной ставке. Саму ставку налога на прибыль для вышеуказанных предприятий целесообразно довести до 15,5\%, вместо применяемой - 20\%, с обязательным принятием закона на уровне субъекта РФ согласно абз. 4 п. 1 ст. 284 НК РФ.

Таким образом, снижение ставки налога на прибыль для предприятий АПК, позволит им более успешно осуществлять производственную деятельность, стремиться к минимилации издержек производства и повышению эффективности.

«В АПК средняя рентабельность за прошлый год составила 8\% по стране. Она колеблется от 60\% до 10\%. Важно, чтобы мы имели минимальную рентабельность не $10 \%$, а хотя бы в ближайшие пять лет достигли стабильно показателя 
в 30-35\%, это будет инструмент собственного развития, к которому стремится государство»,заявил первый замминистра сельского хозяйства РФ Джамбулат Хатуов на заседании краевой аграрной конференции в Ставрополе [14]. Исходя из вышеизложенного, имеест смысл применять пониженную налоговую ставку для предприятий АПК, добившихся рентабельности более 10\%, а при достижении рентабельности 35\%, ставку налога следует вернуть на уровень 20\%. Такая мера даст сигнал предприятиям о том, что непосредственно государство заинтересовано в росте их эффективности. Дополнительные финансовые ресурсы, от вышеуказанных поощрительных мер, способны стать стимулом для дальнейшего развития производства и социальной сферы на перерабатывающих предприятиях АПК.

Следует также учитывать специфику вышеуказанных предприятий. Многие из них расположены в небольших городах и поселках и часто являются градообразующими. Поэтому экономическая поддержка перерабатывающих предприятий АПК будет иметь положительное влияние на экономическое развитие муниципальных образований и позволит обеспечить решение ряда проблем имеющихся в региональной экономике.

Таким образом, исходя из положений действующего налогового кодекса РФ, для поощрения перерабатывающих предприятий АПК и повышения их эффективности субъекты РФ могут снижать нагрузку по налогу на прибыль для данных предприятий. При этом региональные бюджеты практически не потеряют средства от снижения ставки налога, подлежащего зачислению в бюджет субъекта РФ, так как повышение эффективности предприятий приведет к росту их прибыли. Более того, региональные бюджеты во многих случаях смогут получить большие поступления, за счет значительного роста объемов прибыли предприятий в результате повышения их эффективности.

\section{Библиографический список}

1. Грибалев Н.П., Игнатьева И.П. Бизнес-план. Практическое руководство по составлению.- СПБ: Белл, 2003. C. 112.

2. Ефимова Е.А. Мировой опыт социального регулирования в системе налогообложения аграрного сектора экономики./ Е.А. Ефимова // Куб ГАУ: науч. журнал. - 2011. - № 74 (10).

3. Зинченко А.П. Сельскохозяйственная статистика с основами социально-экономической статистики: Учебник/ А.П. Зинченко - М.: МСХА, 2008-345с.; Кованов С.И., Свободин В.А. Экономические показатели деятельности сельскохозяйственных предприятий: Справочник.- М.: ВО «Агропромиздат», 1991.- С. 303; Арутюнян, Ф.Г., Головина Л.А и др. Методические подходы к оценке эффективности аграрного производства: Изд-во «Ваш полиграфический партнер», 2014.-С. 164.

4. Иванов И. Планирование и прогнозирование//Плановое хозяйство. - 2008. - № 3.- С. 55-59.

5. Набиуллина Э. С. Приоритеты деятельности на 2008 г. и среднесрочную перспективу // Экономист. - М. 2008. № 4. С. 9.

6. Налоговый кодекс Российской Федерации. Редакция от: 27 декабря 2018 г. - URL: http://nalogkod.ru.

7. Семененко И.С. Потенциал европейской идентичности как ресурса политической интеграции (что показали выборы в Европарламент) // Человек. Сообщество. Управление. 2014. № 3.

8. Экономика предприятия / Хачатуров Т.С., Суша Г.З., Оноприенко Г.К.; под ред. Т.С. Хачатуров.- Мн.: Экономпресс, 2008.- С. 290.

9. Экономика сельского хозяйства: учебник для академического бакалавриата / Н.Я. Коваленко [и др.]; под ред. Н.Я. Коваленко.- М.: Изд-во Юрайт. 2017. - С. 406.

10. Федеральная служба государственной статистики. Территориальный орган Федеральной службы государственной статистики по Курской области. (Курскстат) Курская область в цифрах. Статистический сборник. 2018. http://kurskstat.gks.ru/wps/wcm/connect/rosstat_ts/kurskstat/resources/61d501004165dab68ff28fa3e1dde 74c/\%D0\%9A\%D0\%A3\%D0\%A0\%D0\%A1\%D0\%9A\%D0\%90\%D0\%AF+\%D0\%9E\%D0\%91\%D0\%9B\%D0\%90\%D0\% A1\%D0\%A2\%D0\%AC+\%D0\%92+\%D0\%A6\%D0\%98\%D0\%A4\%D0\%A0\%D0\%90\%D0\%A5+2018+\%D0\%B3..pdf

11. Финансовый механизм государственной поддержки АПК в России и Беларуси: монография / М.Р. Пинская, Е.Ф. Киреева, Т.В. Сорокина; под ред. д-ра экон. наук М.Р. Пинской, д-ра экон. наук Е.Ф. Киреевой.- М.: ИНФРА-М, 2017. - 258 с. - (Научная мысль).

12. О текущей ситуации в агропромышленном комплексе Российской Федерации в декабре 2018 года. Министерство сельского хозяйства Российской федерации (http://mcx.ru/analytics/apk-review/) 
13. Министерство сельского хозяйства Российской федерации (http://mcx.ru/press-service/news/rost-apk-poitogam-2018-goda-sostavil-2-3/)

14. Информационная служба Agrobook.ru. agrobook.ru/news/53603/minselhoz-rentabelnost-predpriyatiy-apkvyrastet-do-35 